\title{
MANUFACTURE OF SUPER LARGE TUNGSTEN SINGLE CRYSTALS IN THE FORM OF ROTATION BODIES
}

\author{
V.O. Shapovalov, Yu.O. Nikitenko, V.V. Yakusha, O.M. Gnizdylo, I.V. Sheiko \\ The E.O. Paton Electric Welding Institute of NAS of Ukraine, Kiev, Ukraine \\ E-mail: nikitenko@paton.kiev.ua; tel.+38(044)200-12-01
}

The results of researches made at creation of technology of manufacturing of super large single crystals of tungsten in the form of plates and of rotation bodies are presented. In E.O. Paton Electric Welding Institute NAS of Ukraine created a unique technology for the production of single crystals of refractory metals in the form of plates $170 \times 160 \times 20 \mathrm{~mm}$, worked out the technology and conducted material studies, which confirmed their quality and gave the basis for further development in this direction. In recent years, the technology of growing super large single crystal tungsten in the form of rotation bodies with a diameter of $85 \mathrm{~mm}$ has been created.

Tungsten is characterized by extremely high and stable mechanical and physical properties over a wide range of temperatures. High thermal resistance with low coefficient of thermal expansion, stability under neutron loading and high density gives hope for use in many spheres with the use of high-power equipment. In the single crystal state, it exhibits anisotropy of properties that significantly increase the performance properties of tungsten products, taking into account the orientation of the structure in the individual elements.

Traditionally, tungsten single crystals are grown as rods with a diameter of $25 \ldots 30 \mathrm{~mm}$. Attempts to grow quality larger-diameter crystals have failed. The reason is the negative impact of a scale factor that cannot be offset by existing technologies. Given the high melting point (W - $3690 \mathrm{~K}$ ), highly concentrated sources of electric heating, such as electron beam or lowtemperature plasma arc, are used to grow single-crystals of tungsten.

Increasing the linear size of single crystals presents two problems: the retention of a large liquid volume metal and high thermo-mechanical stresses in the body of a single crystal. Temperature gradients create thermal stresses in the crystal that in critical cases can destroy the crystal [1]. High thermo-mechanical stresses contribute to the generation of an additional number of dislocations (the dislocation density can reach $10^{7} \ldots 10^{8} \mathrm{~cm}^{-2}$ ) and significant disorientation of the subgrains, which significantly degrades the quality of the structure of single crystals.

The idea of simultaneous use of two different in nature and energy concentration of electric heating sources - plasma and induction was first proposed by specialists of the Institute of Electric Welding. E.O. Paton NAS of Ukraine [2]. Each of these heating sources performs its functions:

- plasma-arc remelts the consumable material (round rod), creates a mobility local metallic bath on preliminary prepared seed crystal (of set orientation) and forms a single crystal body of set configuration;

- induction one prevents the metallic bath from spillage and creates a preset temperature field in the crystal.

The additional heating of the crystal significantly reduces the radial and axial temperature gradients, which helps to reduce the density of dislocations and internal stresses and helps to form a more perfect structure.

The essence of the method is that the plasmatron, in the reciprocating motion, moves a metal bath, which, receiving the metal from the melting rods, forms a crystal layer by layer, reminiscent of the nature of the arc surfacing. After each passage of the plasmatron, the single crystal go down to the height of the deposited layer, thus providing stable conditions for the growing process (Fig. 1).

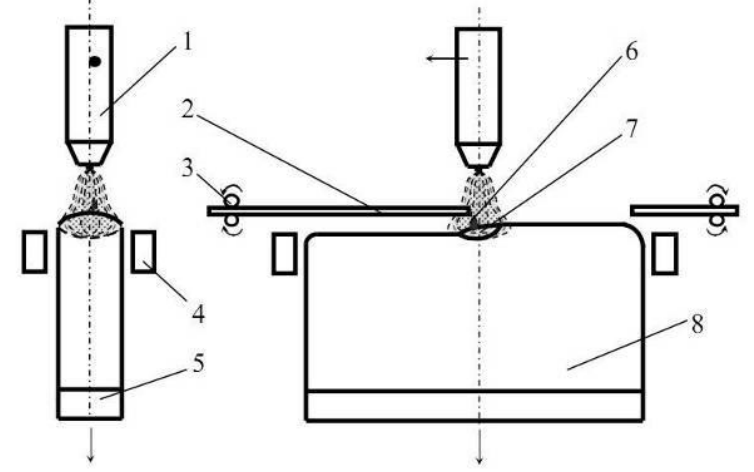

Fig. 1. Scheme of installation for the additive growing of single crystals of refractory metals using the plasma-induction method: 1 - plasmatron;

2 - remelted rod; 3 - the mechanism of feeding rods; 4 -inductor; 5 - seed crystal; 6 -plasma arc; 7 - local bath melt; 8 - single crystal

Previously, using this method, equipment (Fig. 2) and technology for growing profiled single crystals in the form of plates were created (Fig. 3).

The crystal is formed under conditions of heating by the high-frequency field of the inductor to the temperatures characteristic of the hot deformation range. It is known that at these temperatures the movement of dislocations occurs under the action of both external stresses and temperature. Dislocations are not rigidly tied to "their" slip plane and can move from one plane to another, choosing the easiest path. This is seen as an additional degree of freedom of dislocations. With such unregulated movement of dislocations, the probability of their meetings increases, and therefore, on the one hand, the number of cases of their annihilation increases (the density of dislocations decreases), and on the other - the tendency to form regular dislocation 
structures, characterized by the unification of dislocations within low-angle boundaries. The conditions under which the formation of the single crystal occurs provide a higher quality of the single crystal structure than in the ways in which no additional heating (electron beam and plasma arc) is used.

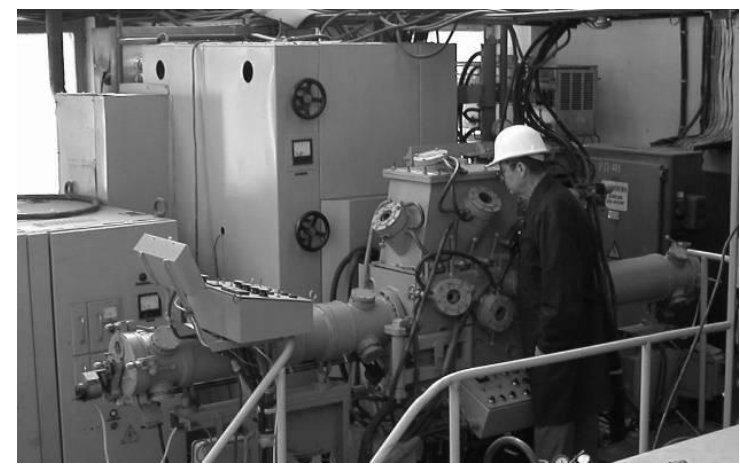

Fig. 2. The equipment for growing single crystals of refractory metals in the form of plates

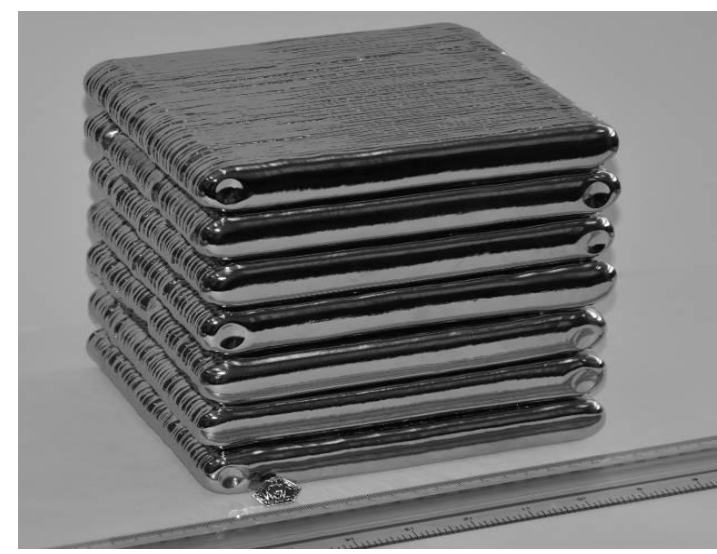

Fig. 3. Appearance of flat tungsten single crvstals $170 \times 160 \times 20 \mathrm{~mm}$

Crystals grown using the above method have a less smooth lateral surface, but this does not prevent their use without additional machining as billets for widescreen rolling.

Interesting are the results of the study of the structure of crystals using optical and X-ray methods. Fig. 4 shows the results of the X-ray study of single crystals.

Comparative studies have shown that the structure of such crystals is more perfect than plasma-arc, and there is practically no macromosaic.

The developed additive technology for the cultivation of large single crystals of refractory metals of technical purity is based on long-lasting thorough researches that allowed to establish and study:

- distribution of thermal fields of single crystals using mathematical models and experimental data [3];

- working ranges of changing technological parameters of the crystal growth process;

- structural characteristics and patterns of structure formation of grown single crystals [4].

Further study of the process allowed to create on the same basis the newest installation for growing super- large single crystals of tungsten in the form of bodies of rotation (Fig. 5)

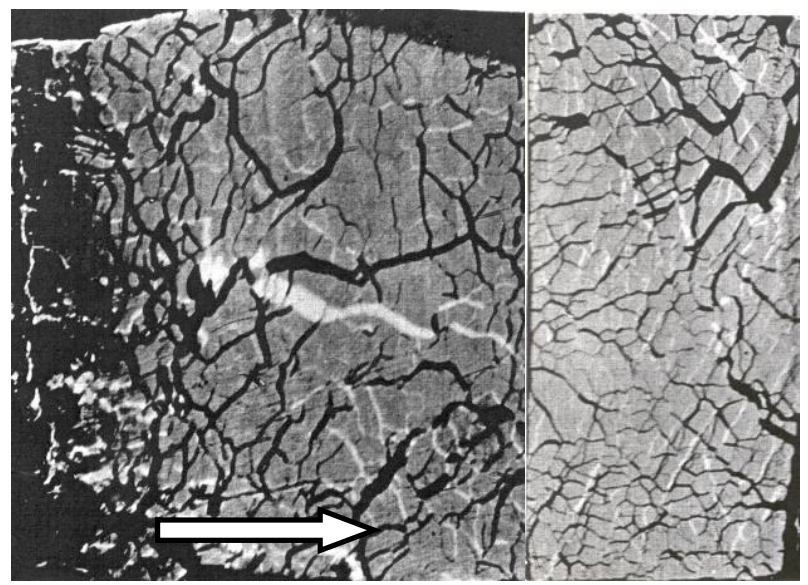

growth direction

$a$ $b$

Fig. 4. X-ray topograms by the Berg-Barrett method; longitudinal (a) and transverse (b) cross section of the crystal

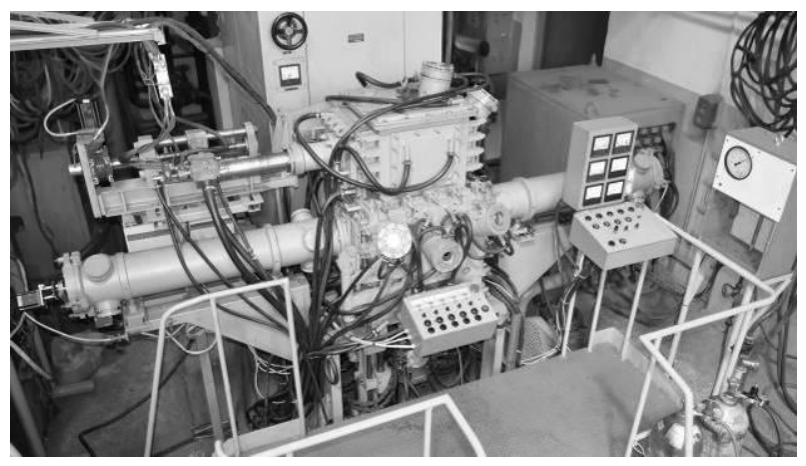

Fig. 5. The newest equipment with computercontrolled unit for the production of single crystals of refractory metals of rotation bodies

The equipment created is a qualitatively new generation of equipment, featuring a fully computerized control system for actuators, motion sensors and single crystal growth control. The design provides for the possibility of growing single crystals in the form of rotation bodies (cylinder or hollow cylinder) with an outer diameter of up to $100 \mathrm{~mm}$ (4 inches). Now a thermal module has been created and the technology of growing tungsten single crystals diameter $85 \mathrm{~mm}$ is being developed.

Fundamentally the technology of growing cylindrical single crystals is based on the technology of growing flat single crystals, but in the new installation, the crystal is continuously rotated around the vertical axis. The crystal seed used is a cylindrical workpiece made of a flat single crystal of predetermined orientation. In Fig. 6 presents a photo of the process of growing a single crystal, where the arrows indicate the rod movement direction into the melting zone of the plasma arc and the direction of rotation of the single crystal. 


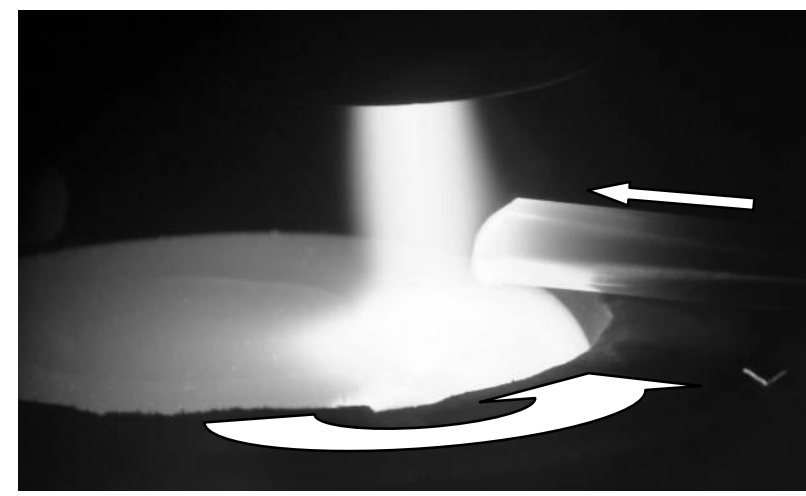

Fig. 6. The process of growing a single crystal of tungsten in the form of rotation body

The growing occurs in layers by moving the local bath and the plasmatron from the central part to the peripheral one so that the liquid bath covers the entire surface and the pre-deposited layer. After deposition of the layer on the entire upper surface of the crystal, it is lowered to the go down. The equipment allows to apply rods on both sides, as in the center of a crystal, and with radial displacement concerning the center.

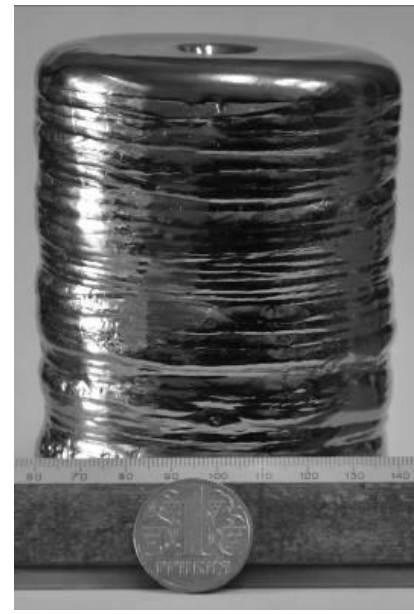

Fig. 7. The appearance of a tungsten crystal with a diameter of $85 \mathrm{~mm}$

Currently, the study of the thermal state in the area of ingot formation and the development of technological modes of crystal growth $\varnothing 85 \mathrm{~mm}$ (Fig. 7). At this stage of technology development, a preliminary evaluation of the single crystallinity of the obtained ingot was carried out by chemical etching of the surface in a mixture of equal volumetric parts of hydrofluoric and nitric acids.
The surface of the ingot thus etched had a characteristic of single crystals in the shape of a cylinder, longitudinally matt and shiny stripes, which replaced each other. The nature of the distribution of the bands testified to the inheritance of the single crystal structure given by the seed crystal and the absence on the lateral surface of the ingot of sub-blocks with a different crystallographic orientation. The study of the degree of perfection of the structure of the obtained single crystal requires additional and deeper research and will be highlighted in future papers.

Single crystals of refractory metals (tungsten, molybdenum) can find an alternative application, both in the form of wide-format rolled metal (sheets, thermal screens), and in the form of articles made of ingots. The most promising applications may be: X-ray technology (electrodes), electronics (sputtering targets, crucibles), electrical engineering (contacts), laser technology (mirrors for optical and X-ray lasers), nuclear power (thermionic power converters of space power plants, parts of structures reactors), aerospace engineering (nozzles).

\section{REFERENCES}

1. G. Marinelli, F. Martinaa, S. Gangulya, S. Williams. Development of Wire + Arc Additive Manufacturing for the production of large-scale unalloyed tungsten components // International Journal of Refractory Metals and Hard Materials. 2019, v. 82, p. 329-335.

2. V.A. Shapovalov, V.V. Yakusha, A.N. Gnizdylo, and Yu.A. Nikitenko. Application of additive technologies for growing large profiled single crystals of tungsten and molybdenum // The Paton Welding Journal. 2016, N 5-6, p. 134-136.

3. V.A. Shapovalov, V.V. Yakusha, Yu.A. Nikitenko, V.V. Dolinenko, A.N. Gnizdylo, V.V. Zholud. Studying the temperature field of profiled tungsten single-crystals produced by plasma-induction process // Advances in Electrometallurgy, Translated from Sovremennaya Elektrometallurgiya. 2014, N 3, p. 31-35.

4. G.M. Grigorenko, L.I. Markashova, E.N. Berdnikova, V.A. Shapovalov, E.V. Polovetskii, V.V. Yakusha, Yu.A. Nikitenko, and A.N. Gnizdylo. Structure and properties of profiled tungsten single-crystals produced by method of plasma-induction growing // 6-th International Samsonov conference "Materials science of refractory compounds". May 22-24, 2018. Kyiv, Ukraine, p. 34.

Article received 14.11.2019

\section{ПОЛУЧЕНИЕ СУПЕРБОЛЬШИХ МОНОКРИСТАЛЛОВ ВОЛЬФРАМА В ВИДЕ ТЕЛ ВРАЩЕНИЯ}

\section{В.А. Шаповалов, Ю.А. Никитенко, В.В. Якуща, А.Н. Гниздыло, И.В. Шейко}

Представлены результаты исследований, проведенных при создании технологии получения супербольших монокристаллов вольфрама в виде пластин и тел вращения. В ИЭС им. Е.О. Патона НАН Украины была создана уникальная технология выращивания монокристаллов тугоплавких металлов в виде пластин 170×160×20 мм, отработана технология и проведены материаловедческие исследования, которые 
подтвердили их качество и создали основу для дальнейших разработок в этом направлении. В последние годы было создано новую не имеющую мировых аналогов технологию выращивания супербольших монокристаллов вольфрама в виде тел вращения диаметром 85 мм.

\section{ОТРИМАННЯ СУПЕРВЕЛИКИХ МОНОКРИСТАЛІВ ВОЛЬФРАМУ У ВИГЛЯДІ ТІЛ ОБЕРТАННЯ}

\section{В.О. Шаповалов, Ю.О. Никитенко, В.В. Якуша, О.М. Гніздило, І.В. Шейко}

Представлено результати досліджень, проведених при створенні технології отримання супервеликих монокристалів вольфраму у вигляді пластин та тіл обертання. В IE3 ім. Є.О. Патона НАН України була створена унікальна технологія вирощування монокристалів тугоплавких металів у вигляді пластин 170×160×20 мм, відпрацьована технологія та проведені матеріалознавчі дослідження, що підтвердили їхню якість та дали підгрунтя для подальших розробок у цьому напрямку. В останні роки було створено новітню, не маючу світових аналогів, технологію вирощування супервеликих монокристалів вольфраму у вигляді тіл обертання діаметром 85 мм. 